\section{Turn Political Mudslinging into Tasty Educational Treats: Incorporating Political Campaigns into Psychology Courses}

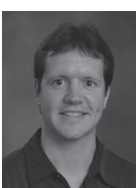

Geoffrey D. Munro, Towson University Michael R. Hulsizer, Webster University

Every four years in the United States, the framers of the U.S. Constitution provide a gift to psychology teachers - the presidential campaign and election. The presidential election provides numerous opportunities for teachers who appreciate the utility of using real world events to improve students' understanding of psychological concepts in a wide variety of courses. The paragraphs that follow contain ideas for illustrative examples, classroom discussions, assignments, activities, and mini-experiments that incorporate the presidential campaign and election into psychology courses.

\section{Source Characteristics}

A fundamental aspect of any political campaign is the candidate. Some of the variables that appear to be moderately associated with leadership success include (in no particular order): charisma, a desire for power and dominance, self-confidence, self-direction, morality, and intelligence (Bass \& Stogdill, 1990). Students could be asked to make predictions about which personality traits and constructs might predict voter preferences for certain candidates or issues. This could then be followed by an assignment to review the research literature on personality traits and voting preferences. Additionally, the intense media exposure of candidates' lives provides fertile ground for personality assessments of the candidates. A case study assignment of current or past presidential candidates would certainly prove interesting to students and instructors alike. The results of any of these assignments could then be contrasted with research suggesting that only three personal attributes of U.S. presidents have been shown to predict effectiveness in office (as rated by historians): height, family size, and the number of books published prior to taking office (Simonton, 1987).

In recent years, voters have been increasingly more likely to receive information about a candidate from advocacy groups (e.g., MoveOn.org, Swift Boat Veterans for Truth), political pundits (e.g., Al Franken, Bill O'Reilly), political provocateurs (e.g., Michael Moore), and comedy shows (e.g., The Daily Show) than from the candidates themselves. Thus, a discussion of the partisan nature of such "news" sources can provide an excellent opportunity to enhance a critical thinking discussion. Finally, the role of the traditional mass media in influencing the perceptions of candidates and their policies as well as affecting the importance of different issues in voters' minds could spark a healthy discussion. A class could discuss the evidence surrounding the "vast right-wing conspiracy" or the "liberal bias" among traditional news sources. For example, the recent film Outfoxed: Rupert Murdoch's War on Journalism (Greenwald, 2004) contains a number of techniques that the filmmaker suggests are used by the Fox News channel to influence viewers, thus the film might help to initiate a lively discussion about the media's position in presidential politics.

\section{Message Characteristics}

The most obvious means by which the presidential campaign can be incorporated into psychology courses involves the "packaging of the presidency." Indeed, an enormous amount of time and money is devoted to making the candidate appeal to as many voters as possible (Jamieson, 1996; Jamieson \& Waldman, 2001). Instructors might find the presidential campaign particularly amenable to teaching the social psychological topic of attitudes and persuasion. Attitudes toward the candidates or the political parties could be used to illustrate the structure and functions of attitudes. A discussion of which attitude components (i.e., affective, behavioral, and cognitive) are stronger in political attitudes and what functions (e.g., social acceptance, value-expressive, utilitarian) are best served by political attitudes would be thought-provoking. For example, in an intriguing application of terror management theory, researchers found that, compared to a control group, participants forced to examine their own mortality (e.g., reminded of 9/11) were more likely to support President George W. Bush (Landau et al., 2004). It may be informative to have students assess the degree to which these research findings are being utilized in the Bush reelection campaign.

The consistency between attitudes toward candidates or other politica issues and political behaviors like voting, volunteering, or donating money would serve as an effective framework for the issue of attitude-behavior consistency. For the topic of persuasion, assignments could be constructed in which students identify and analyze the persuasion techniques (e.g., humor, fear) used in convention speeches, political television advertisements, and debates. Numerous videotapes exist of past campaign ads and debates. MoveOn.org has a series of 30 second anti-Bush ads available for a nominal fee. In addition, candidate, party, and advocacy group web sites contain numerous examples of such material via video streaming.

The area of social cognition is also ripe for integration of election material. For example, a lecture on social identity theory can be augmented by discussing the impact of incorporating political ideology into one's sense of identity - such as examples of candidates and supporters using enmity to devalue the outgroup (i.e., democrat, republican) relative to their ingroup (e.g., Krugman, 2004). Numerous examples of ingroup/outgroup biases, illusory correlations, confirmation biases, and belief perseverance effects exist in the statements made by the candidates and their supporters during interviews, press releases, and television ads - many of which are readily available on candidate, party, or advocacy group web sites. To further illustrate this process, it would be useful to have students identify the different stereotypes used by the candidates to define themselves and their opponents (e.g., flip-flopper, Texas gunslinger, Massachusetts liberal, compassionate conservative). Students could brainstorm ideas about how prejudices might impact the presidential campaign. In addition to provoking thought about the crucial role of gender, race, sexual preference, and religion in our society, this activity could potentially improve students' understanding of concepts like symbolic racism via an identification of political symbols (e.g., the Willie Horton television advertisement or the gay marriage issue) in presidential campaigns (Sears, Lau, Tyler, \& Allen, 1980).

To illustrate motivated reasoning processes (e.g., Jost, Glaser, Kruglanski, \& Sulloway, 2003), the biased processing of campaign information by political partisans, an instructor might conduct an in-class study by having students report their candidate preferences before watching a presidential debate and then having them evaluate the debaters immediately afterwards. Research suggests that those with pre-debate preferences will evaluate the debate in a way that confirms their preferences and might even report strengthening their preferences after the debate (Munro, Ditto, Lockhart, Fagerlin, Gready, \& Peterson, 2002). Motivated reasoning processes are not limited to debate evaluations, students could analyze campaign statements and information to identify other examples of motivated reasoning processes. For example, some politicians are adept at using the self-serving bias, taking responsibility for successes (e.g., economic upturns) but placing blame elsewhere for failures (e.g., economic recessions). Additionally, partisans are skilled at molding historical information, like John Kerry's military service in Vietnam, to fit their political worldview (e.g., Hulsizer, Munro, Fagerlin, \& Taylor 2004). Another reasoning bias that is likely to play out this year in what promises to be a close election is the hindsight bias (Powell, 1988). Miniexperiments assessing students' pre-election predictions and confidence ratings and their post-election recollections might prove a fitting example of the hindsight bias.

\section{Target Group Characteristics}

One key element of political campaigns is delivering a message that resonates with a target group. Whether it is energizing the traditional base of a political party, reaching out to new groups of constituents, or encouraging young adults to vote, political campaigns rise and fall with their ability to get people involved and willing to vote. The goal of developing a message that appeals to as many people as possible often begins by discovering the issues that matter to most voters. Political polling is a topic well-suited for use when discussing research methods. Students could, for example, conduct an analysis of the wording of the stems and response options used by different polls. Of course, the sampling techniques used by polling agencies can also be critically analyzed. Polls often report results for "registered voters" or "likely voters", so students could evaluate the representativeness of these samples. This would be especially interesting in light of famous polling mistakes like the "Dewey defeats Truman" headline and the premature calls of the Florida vote in 2000 . Given the tendency of polling agencies to survey land-line telephones versus cell phones (Breslin, 2004 ) one can only wonder if the same issues will arise in 2004. Finally, the margin of error included in poll results livens a discussion of confidence intervals.

An interesting discussion can also be structured around the difficulty candidates have tapping into young voters. Instructors might encourage students to speculate why this population is particularly difficult to reach and then offer suggestions, using psychological principles and techniques, to increase young voter turnout. For example, students might utilize Cialdini's (2001) compliance principles, reference cognitive dissonance, or discuss the elaboration likelihood model of persuasion when developing a strategy 
to encourage voting behavior among young adults. Conclusion

Incorporating current political campaigns into the classroom provides a unique opportunity to increase the salience and relevance of many of the psychological theories and research programs discussed in a wide variety of courses. Although there are clear benefits to enhancing lectures with examples from the current presidential campaign, there are dangers. Instructors need to be cognizant that students may not share their political beliefs. Consequently, it is important to create a non-threatening classroom environment for all students but especially for those who might be in the political minority. Teaching will be most effective when students, regardless of their political affiliations, pursue the application of psychological concepts to all candidates and all political parties rather than seeking to portray one candidate or one party in a negative light and another in a positive light. In a non-threatening classroom, the potential benefits of infusing political campaign discussions into the classroom are numerous. First, students are more likely to understand concepts when they can readily see the applications of these ideas in a real world setting. Second, navigating the political landscape of a presidential campaign offers important lessons on the value of being a critical consumer of information. Finally, young adults tend to be one of the least likely groups to vote. Consequently, discussing currently political campaigns may increase civic engagement for students.

\section{References}

Bass, B. M. \& Stogdill, R. M. (1990) Bass and Stogdill's handbook of leadership: Theory, research, and managerial applications, ( $3^{\text {rd }}$ ed.). New York: Free Press.

Breslin, J. (2004, September 16). Making call on sham of political polling. Newsday.com. Retrieved September 23, 2004 from http://www.newsday. com/news/columnists/ny-nybres163973220sep16,0,5025667.column

Cialdini, R. B. (2001). Influence: Science and practice $\left(4^{\text {th }}\right.$ ed.). Needham Heights, MA: Allyn and Bacon.

Greenwald, R. (Producer/Director). (2004). Outfoxed: Rupert Murdoch's War on Journalism [Motion picture]. United States: Carolina Productions.

Hulsizer, M. R., Munro, G. D., Fagerlin, A., \& Taylor, S. (2004). Molding the past: Biased assimilation of historical information. Journal of Applied Social Psychology, 34, 1048-1074.

Jamieson, K. H. (1996). Packaging the Presidency (3rd ed.). New York: Oxford University Press.
Jamieson, K., \& Waldman, P. (2001). Electing the President, 2000: The insiders' view. Philadelphia: University of Pennsylvania Press.

Jost, J. T., Glaser, J., Kruglanski, A. \& Sulloway, F. J. (2003). Political conservatism as motivated social cognition. Psychological Bulletin, $129,339-375$

Krugman, P. (2004, September 3). Feel the hate [Electronic version]. The New York Times, p. A19.

Landau, M. J., Solomon, S., Greenberg, J., Cohen, F., Pyszczynski, T., Arndt, J., et al. (2004). Deliver us from evil: The effects of mortality salience and reminders of 9/11 on support for President George W. Bush. Personality and Social Psychology Bulletin, 30, 1136-1150.

Munro, G. D., Ditto, P. H., Lockhart, L. K., Fagerlin, A., Gready, M., \& Peterson, E. (2002). Biased assimilation of sociopolitical arguments: Evaluating the 1996 U.S. Presidential Debate. Basic and Applied Social Psychology, 24, 15-26.

Powell, J. L. (1988). A test of the knew-it-all-along effect in the 1984 presidential and statewide elections. Journal of Applied Social Psychology, 18, 760-773.

Sears, D. O., Lau, R. R., Tyler, T. R., \& Allen, H. M., Jr. (1980). Self-interest vs. symbolic politics in policy attitudes and presidential voting. American Political Science Review, 74, 670-684.

Simonton, D. K. (1987). Why presidents succeed: A political psychology of leadership. New Haven, CT: Yale University Press.

\section{Related Resources}

Fritz, B., Keefer, B., \& Nyhan, B. (2004). All the President's spin: George W. Bush, the media, and the truth. New York: Touchstone.

Isbell, L. M. (2003). Teaching an undergraduate course in political psychology. Teaching of Psychology, 30, 148-153.

Levin, S. (2000). Undergraduate education in political psychology. Political Psychology, 21, 603-620.

Monroe, K. R. (Ed.) (2002). Political psychology. Mahwah, NJ: Lawrence Erlbaum and Associates.

Opensecrets.org (2004). Your guide to money in the elections. Retrieved September 23, 2004 from http://www.opensecrets.org - Nice source for information on 501(c), 527, and other advocacy groups.

Washington Post (2004). Data Directory. Retrieved September 23, 2004 from http://www.washingtonpost.com/wp-srv/politics/polls/datadir.htm - Nice source for relevant public opinion data published on the Internet by nonpartisan organizations.

\section{Announcing the APA \\ Psychology Department Program}

The APA Education Directorate announces a new opportunity to take advantage of the benefits and resources offered by APA. Through the APA Psychology Department Program, undergraduate and graduate psychology departments can purchase a package that includes subscriptions to APA's many teaching and advising publications and promotes access to its varied education resources.

Departments that participate in the program receive subscriptions to various APA magazines and newsletters. Departments receive copies of the APA books, Graduate Study in Psychology and the Publication Manual. As an added benefit, departments will also receive a copy of the Careers in Psychology video, highlighting diverse psychology careers, and the Resource Guide for Departments, which lists information on teaching awards, small grants for teaching conferences, and undergraduate research opportunities.

The program provides annual subscriptions to:

* Monitor on Psychology, the monthly news magazine of the APA,

* GradPSYCH, a quarterly magazine for that provides graduate students with cutting-edge information on innovative psychology careers; financial information, training and supervision; graduate student lifestyle issues; and emerging trends in psychology practice, research, and education,

* Psychology Teacher Network, a quarterly newsletter that offers tips on teaching introductory psychology and notices on psychology teaching conferences, and

* The Educator, a biannual newsletter on trends and issues in psychology education and psychology in education.

Other benefits include:

* A Psychology Club Certificate, a certificate of congratulations from APA in recognition of your campus psychology club,

* The "Behavior Matters" booklet describing how behavioral research makes a difference in everyday life,

* A limited number of complimentary APA Student Affiliate Memberships that can be offered to your outstanding students, and

* Website links of participating schools as a means of showcasing psychology departments and facilitating partnerships between them.

Look for more details about the APA Psychology Department Program on the web at: http://www.apa.org/ed/pcue/psydeptprog.html. If you have any questions about the APA Psychology Department Program, please call the Office of Precollege and Undergraduate Education at 1-800-374-2721, $x-6140$ or contact us through email at: mmccarthy@apa.org or mboenau@apa.org. 